\title{
Mikrofluidikai cella fejlesztése folyadékfázisú vékonyréteg-leválasztás nyomon követésére
}

\section{Development of microfluidic cell for liquid phase layer deposition tracking}

\author{
Renkó József Bálint, ${ }^{1}$ Bonyár Attila, ${ }^{2}$ Szabó Péter János ${ }^{3}$ \\ Budapesti Müszaki és Gazdaságtudományi Egyetem, Anyagtudomány és Technológia Tanszék, Budapest, \\ Magyarország \\ ${ }^{1}$ renko.jozsef@edu.bme.hu \\ ${ }^{2}$ bonyar@ett.bme.hu \\ ${ }^{3}$ szpj@eik.bme.hu
}

\begin{abstract}
This paper shows how microfluidic tools can be used for up-to-date microstructural investigations based on thin film deposition. The construction and production methods of such measuring procedures are introduced, and their application in ellipsometric investigations is shown. By using these tools, the researchers provide the possibility to observe and document the effects of certain fine structural processes in the development of the final microstructure. This paper describes two specific application areas of such microfluidics cells. Microfluidics cells can be used together with both optical microscopy and spectroscopic ellipsometry to understand previously unexplored microstructural changes.
\end{abstract}

Keywords: microfluidics, material science, rapid prototyping, in situ material testing.

\section{Összefoglalás}

Cikkünkben azt mutatjuk be, hogyan használhatók korszerű, rétegépítésen alapuló mikroszerkezet-vizsgálatra (pl. színes maratásra) a mikrofluidikai alapokon működő eszközök. Ismertetjük egy ilyen elven működő mérési elrendezés tervezési és előállítási módszereit, valamint bemutatjuk az elkészített vizsgálóegység felhasználhatóságát ellipszometriai vizsgálatok elvégzésére. Ezzel az eszközzel lehetőségünk nyílik egyes mikroszerkezeti folyamatoknak a szövetszerkezet-változásra gyakorolt hatását valós időben megfigyelni és dokumentálni. A cikk a mikrofluidikai cellák két alkalmazási területét mutatja be példákon keresztül. Ezek a mikrofluidikai cellák optikai mikroszkópiával párosítva, ill. spektroszkópiai ellipszometriával kombinálva is használhatók az eddig fel nem térképezett mikroszerkezeti változások megértéséhez.

Kulcsszavak: mikrofluidika, anyagtudomány, gyorsprototípus-gyártás, in situ anyagvizsgálat.

\section{Bevezetés}

A technológia fejlődésével jelentős javulásnak indult az előállítható anyagok minősége. Ezzel párhuzamosan egyre nagyobb lett az igény korszerü anyagvizsgálati módszerek kifejlesztésére [1]. A jelenleg használt gyártási és anyagvizsgálati módszerek egy része viszont a mai napig olyan eljárásokat alkalmaz, amelyeknél a végbemenő jelenségek pontos fizikai háttere még nem vagy nem teljesen tisztázott.

Erre kiváló példa a maratási eljárások egy jelentős része, különösen a színes maratás. Az optikai mikroszkópos mikroszerkezeti vizsgálatoknál a maratás mindennapos vizsgálati módszernek számít, amely segítségével a szövetszerkezet elő- 
hívható a csiszolt mintákon [2]. Gyakori alkalmazása ellenére számos marószernél a mai napig nem sikerült folyamatában feltárni a maratás során végbemenő mikroszerkezeti változásokat [3], holott kísérletek történtek a maratás során kialakult színek és egyes fémtani tulajdonságok közti összefüggések feltárására [4, 5].

A gyors prototípusgyártás egyre szélesebb körü elterjedésével, valamint a polimer alapanyagok fejlődésével egy új lehetőség jelent meg a mikroszerkezeti változások nyomon követésére. Az additív gyártási eljárások mára elérték azt a méretpontosságot, ami ahhoz szükséges, hogy akár néhány tizedmilliméter átmérőjű csatornákat is ki lehessen alakítani [6]. A megfelelő alapanyagok felhasználásával olyan mikrofluidikai cellák alkothatók meg, amelyekben a marószer zárt rendszerben, szabályozott körülmények között áramoltatható [7]. A mikrofluidikai cella kialakításától függően kombinálható a metallográfiában eddig is használt eszközökkel, mint például az optikai mikroszkóppal vagy a spektroszkópiai ellipszométerrel. Így a maratás folyamata nemcsak diszkrét időpillanatokban válik vizsgálhatóvá, hanem folyamatában is.

\section{Kísérleti munka}

\subsection{Mikrofluidikai cellák tervezése}

Munkánk során két különböző cella terveit készítettük el. A cellák tervezésénél ügyelni kell arra, hogy az elkészült rendszer beépíthető legyen a vele együtt használni kívánt berendezésbe. A geometria biztosítására a mintát be kellett ágyazni, hogy a geometriájától függetlenül vizsgálni lehessen.

$\mathrm{Az}$ első mikrofluidikai cella úgy lett kialakítva, hogy az egy optikai mikroszkóppal kompatibilis legyen. Ezzel lehetőség nyílik a maratási, rétegépülési folyamatok valós idejü optikai nyomon követésére [8].
A nagyítás növelésével az objektív és a vizsgálandó minta felülete között egyre kisebb lesz a fókusztávolság, ezért a maximális felbontást már a tervezés során figyelembe kellett venni. A rendelkezésre álló Olympus BX51 típusú, LMPlan FI50/0.50 nagy fókusztávolságú objektívvel felszerelt fordított állású mikroszkóp esetében a maximális nagyításnál a fókusztávolság 3,6 mm. A marószer áramlását a kialakított csatornarendszer biztosítja. Mivel az éles képhez megfelelő távolságot kell tartani a mikroszkóp objektívje és a vizsgált tárgy között, ezért a cellát az 1 . ábrán látható módon üveglap zárja le. A tervezésnél figyelembe vett méretezési megfontolásokat szintén az 1. ábra mutatja. A kész eszközön kialakítottunk egy peremet a minta és a cella találkozásánál, amely a minta cseréjét könnyíti meg (2. ábra).

A második mikrofluidikai cellát kifejezetten spektroszkópiai ellipszométerhez alakítottuk ki. Az ellipszometriával lehetőségünk nyílik nanométeres pontossággal mérni a felületi rétegvastagságot, vizsgálni az optikai törésmutatót, a homogenitást vagy akár a felületi érdességet [9].

$\mathrm{Az}$ ellipszometria különösen érzékeny a határfelületeken fellépő fénytörésre, ezért a cellát úgy kell kialakítani, hogy a vizsgálathoz használt fénysugár minden átlépő határfelületen merőlegesen haladjon keresztül, egészen a minta felületéig, így biztosítva a maximális fényintenzitást és az alacsony zajszintet. Figyelembe kellett továbbá venni, hogy a rendelkezésre álló, Woollam M-2000DI típusú spektroszkópiai ellipszométer esetén a fénysugár az adóból kilépve megközelítőleg $3 \mathrm{~mm}$ átmérőjü, ami a minta felületére érve a tizedére csökken (3. ábra).

A minta cellában történő rögzítése esetén ezért ki kell alakítani egy olyan mozgatómechanizmust, ami lehetővé teszi, hogy a fénysugár a vizsgálandó felület bármely pontjára fókuszálható legyen. A mikrofluidikai cellát ezért nem egy, hanem két, egymáson elcsúsztatható félből kell kialakítani.

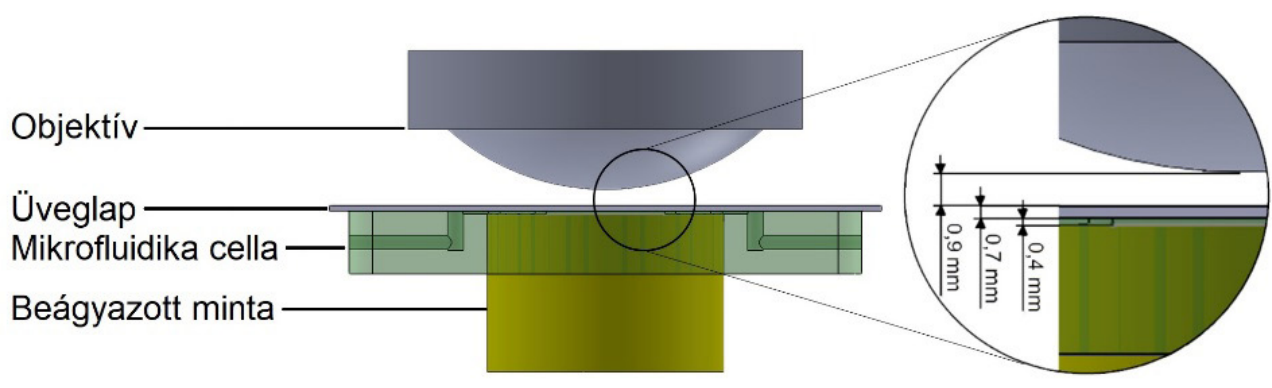

1. ábra. Az optikai mikroszkóppal használható mikrofluidikai cella vizsgálat szempontjából fontosabb méretei 


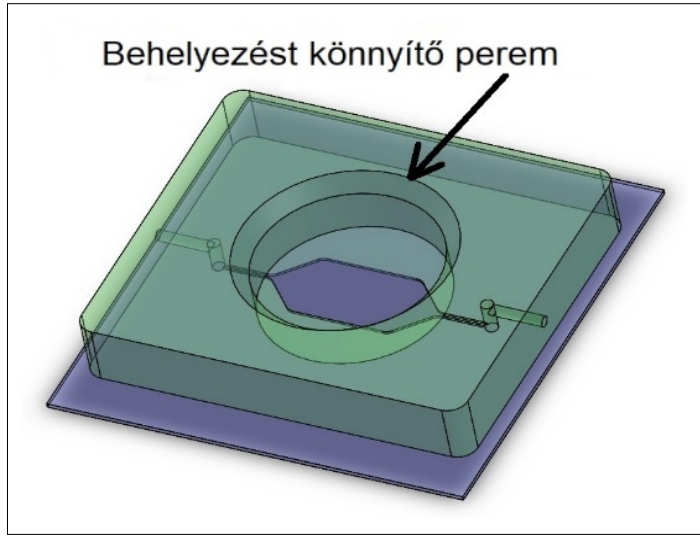

2. ábra. Az optikai mikroszkóppal használható mikrofluidikai cella tervezett kialakítása

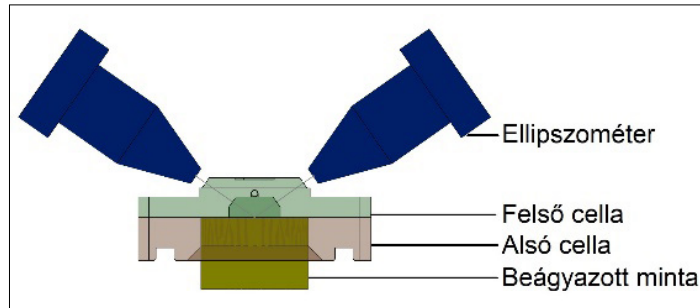

3. ábra. Ellipszométerrel használható mikrofluidikai cella tervezett kialakítása

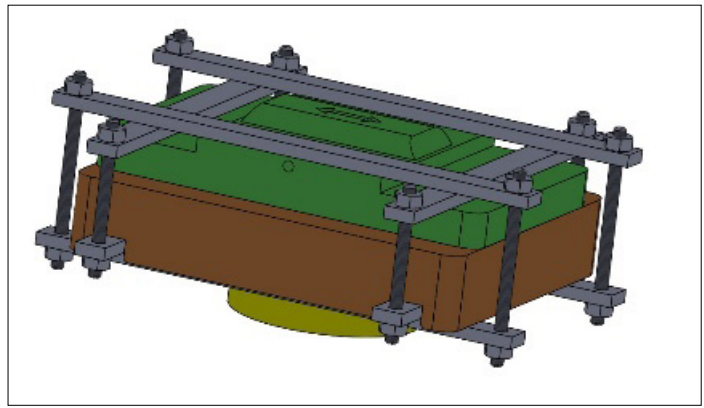

4. ábra. Ellipszométerrel használható mikrofluidikai cellát rögzítő eszköz

A felső cellafél biztosítja a marószer áramlását és a vizsgálathoz szükséges beesési szögeket, míg az alsó cellafél a minta rögzítését és pozicionálását hivatott megoldani. A két cellafél a 4. ábrán látható módon rögzíthető egymáshoz.

\subsection{Mikrofluidikai cellák gyártása}

A mikrofluidikai cellák gyártásához kémiailag inert, átlátszó anyagot kell választani, amely nem lép reakcióba sem a mintával, sem a marószerrel, továbbá képes a fényt átengedni. Alapanyagnak

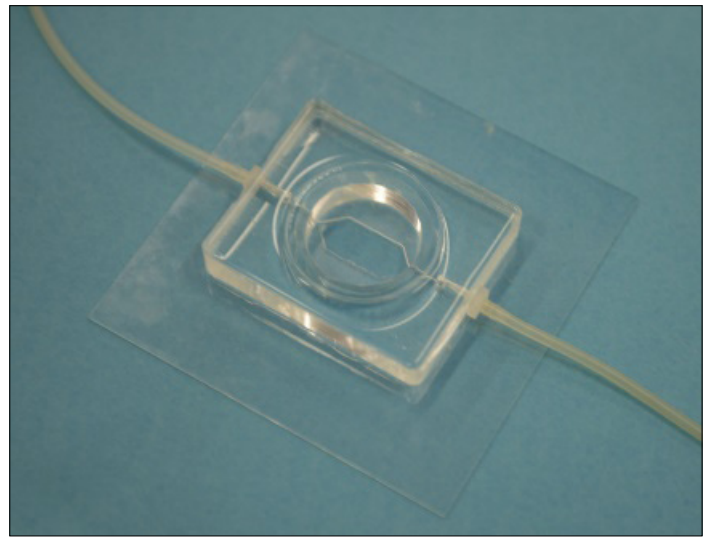

5. ábra. Legyártott, optikai mikroszkóppal használható mikrofluidikai cella a hozzácsatlakoztatott szilikoncsövekkel

poli(dimetil-sziloxán)-t (PDMS) választottunk, amely a mikrofluidikai cellák gyártásánál már jól bevált agyag. A PDMS monomerjét 10:1 arányban keverve a reagenssel, a nagy viszkozitású keverékben megindul a térhálósodás. A keverék öntőformába töltése után kemencében, $100{ }^{\circ} \mathrm{C}$-on kell hőkezelni 60 percig. Az öntőformák mindkét cella esetében Objet Eden 250 típusú 3D-s nyomtatóval készültek.

Az optikai mikroszkóppal használható cella alsó felét koronakisüléssel hozzárögzítjük egy üveglaphoz, így zárva le a cellát. A kötés megerősítésére, a kész cellát az üveglaphoz préselve, további 30 percig $60{ }^{\circ} \mathrm{C}$-on, kemencében hőn tartjuk. Az így kialakított cella belső csatornájának térfogata $205 \mathrm{~mm}^{3}$ (a mintadarabbal lezárva) (5. ábra).

Az ellipszométerhez gyártott cella esetében az üveglap nem biztosítaná a fény merőleges be- és kilépési szögét, így a cella alsó és felső részét is PDMS öntésével kell elkészíteni. Ezek a 4. ábrán már bemutatott módon rögzíthetők egymáshoz. A cella belső csatornájának térfogata ebben az esetben $851 \mathrm{~mm}^{3}$.

\section{A mikrofluidikai cellák használata}

A cella be- és kimeneti nyílásai szilikoncsövekkel csatlakoztathatók a lamináris áramlást biztosító fecskendőpumpához. Az így kialakított berendezés alkalmas arra, hogy a maratás teljes időtartama alatt különböző eszközökkel kövessük nyomon a minta felületén lejátszódó folyamatokat. A technika az első cella esetében a digitális képrögzítést, a második cella esetében pedig a minta felületén a rétegnövekedés okozta interferencia-változás rögzítését teszi lehetővé. 
Bár a mikrofluidikai rendszerek használata kiszélesíti a mikroszerkezet-vizsgálat lehetőségeit, a rendszer korlátait sem szabad figyelmen kívül hagyni. Mikroszkópos vizsgálatoknál a használt objektív fókusztávolsága miatt a nagyítás mértéke nem növelhető korlátlanul. A nagyítás korlátja miatt vizsgálható legkisebb szemcseméret megközelítőleg 3-5 $\mu \mathrm{m}$. Az ellipszometriához fejlesztett cella esetében pedig a fény útjának biztosítására a cella belső csatornáinak méretei kötöttek, így mérés előtt a teljes térfogatot fel kell tölteni a használni kívánt marószerrel. Mivel a mikrofluidikai rendszer feltöltése időt vesz igénybe, ezért a maratás kezdeti szakasza nem rögzíthető.

\section{Következtetések}

Mikrofluidikai rendszerek használatával lehetőség nyílik in situ mikroszerkezeti vizsgálatok elvégzésére, amelyekkel a maratási, illetve vékonyréteg-növesztési folyamatok nyomonkövethetősége jelentős mértékben javulhat. A technológia nyilvánvaló hátrányai ellenére is kiválóan alkalmazható a mikroszerkezeti vizsgálatokra alkalmas berendezésekkel. A zárt rendszerének köszönhetően pedig biztonságosan alkalmazható akár korróziós, akár maratási, akár rétegépülést vizsgáló eljárásokban.

\section{Köszönetnyilvánítás}

A kutatás az Emberi Erőforrások Minisztériuma ÚNKP-18-3-I-BME-266 kódszámú Új Nemzeti Kiválóság Programjának támogatásával készült.

A publikáció az Emberi Erőforrások Minisztériuma NTP-SZKOLL-19-066 kódszámú Nemzeti Tehetség Program pályázatának támogatásával valósult meg.

\section{Szakirodalmi hivatkozások}

[1] Leuders S., Thöne M., Riemer A., Niendorf T., Tröster T., Richard H. A., Maier H. J.: On the Mechanical Behaviour of Titanium Alloy TiAl6v4 Manufactured by Selective Laser Melting: Fatigue Resistance and Crack Growth Performance. International Journal of Fatigue, 48. (2013) 300-307. https://doi.org/10.1016/j.ijfatigue.2012.11.011.
[2] Beraha E.: New Metallographic Reagents for Stainless Steel and Heat-Resisting Alloys. J. Iron Steel Inst., March (1966), 248-251.

[3] Schaberger E., Grote F., Schievenbusch A.: Colour Etching and Coloured Image Analysis - A Way of Characterising the Microstructures of Innovative Cast Materials. Praktische Metallographie/Practical Metallography, 37. (2000) 419-434.

[4] Bonyár A., Szabó P. J.: Correlation Between the Grain Orientation Dependence of Color Etching and Chemical Etching. Microscopy and Microanalysis, 18/6. (2012) 1389-1392. https://doi.org/10.1017/S1431927612013554

[5] Szabó P. J., Bonyár A.: Effect of Grain Orientation on Chemical Etching. Micron, 43/2-3. (2012) 349351.

https://doi.org/10.1016/j.micron.2011.09.015

[6] Takagishi K., Umezu S.: Development of the Improving Process for the 3D Printed Structure. Scientific Reports, 7. (2017) art. 39852.

https://doi.org/10.1038/srep39852

[7] Bonyár A., Sántha H., Ring B., Varga M., Kovács J. G., Harsányi G.: 3D Rapid Prototyping Technology (RPT) As a Powerful Tool in Microfluidic Development. Procedia Engineering, 5. (2010) 291-294.

[8] Bonyár A., Renkó J., Kovács D., Szabó P. J.: Understanding the Mechanism of Beraha-I Type Color Etching: Determination of The Orientation Dependent Etch Rate, Layer Refractive Index and a Method for Quantifying the Angle Between Surface Normal and the ‘100〉, ‘111〉 Directions for Individual Grains. Materials Characterization, 156. (2019) 109844.

https://doi.org/10.1016/j.matchar.2019.109844

[9] Fodor B., Defforge T., Agócs E., Fried M., Gautier G., Petrik P.: Spectroscopic Ellipsometry of Columnar Porous Si Thin Films and Si Nanowires. Applied Surface Science, 421. Part B (2017) 397-404. https://doi.org/10.1016/j.apsusc.2016.12.063 